\title{
Wellbeing and gender equality for the elderly in the context of Arctic Sweden
}

\author{
Lena Wennberg ${ }^{1}$ \\ Forum for Studies on Law and Society, Umeå University, Sweden
}

\begin{abstract}
One theme of importance for gender equality in the Arctic region is the wellbeing of the aging population and how their needs are provided for in private and public spheres -by the family, local communities, the state and the market. In this article, the complexity of the public and private division of welfare provision and care of the elderly in the Swedish Arctic context is addressed and discussed in the light of national, regional and international policy and law. Norrbotten, the northernmost county in Sweden that is part of the Barents Euro-Arctic region, is taken as a frame of reference for critical reflection on wellbeing and gender equality for the ageing population in rural, depopulated and multicultural contexts and the need to develop alternative political and legal interventions that are better adjusted to meet the everyday needs in this specific setting.
\end{abstract}

Keywords: Ageing, gender equality, Arctic Sweden, welfare state policy and law

\section{Introduction}

International interest in the Arctic region has increased with the extraction of natural resources being the focus, but questions about living conditions are also of central interest. From 2011-2013 the Sustainable Development Group (SDWG) initiated projects promoting health and wellbeing in Arctic Activities, such as the Comparative Review of Circumpolar Health Systems Report (CircHSR) ${ }^{2}$ and the Arctic Human Health Initiative (AHHI) (Parkinson 2013). The AHHI is an Arctic Council IPY [International Polar Year] initiative that aims to build and expand on existing Arctic Council and International Union for Circumpolar Health's human health research activities. The overall goal of the AHHI is to: "Increase awareness and visibility of human health concerns of Arctic peoples, foster human health research, and promote health strategies that will improve health and wellbeing of all

\footnotetext{
${ }^{1}$ Corresponding author. Address: Lena Wennberg, Forum for Studies on Law and Society, Umeå University, S-901 87 Umeå, Sweden. E-mail: lena.wennberg@umu.se

${ }^{2}$ Arctic Council's Sustainable Development Working Group [SDWG]. Arctic Human Health Expert Group (AHHEG). 2010. Proposal for a Comparative Review of Circumpolar Health Systems [CircHSR].
} 
Arctic residents". ${ }^{3}$ The latter has increased awareness and visibility of human health concerns; fostered research; and promoted strategies to improve the health and wellbeing of Arctic residents.

Gender equality is also among the issues articulated by the Arctic Council as needing to be taken into account expressed, however, on a more rhetorical level (Lahey, Svensson and Gunnarsson 2014). In reality, equality objectives seem so far to have had little influence on the management of the region although gender equality in the Arctic and the current realities and future challenges were discussed on a conference held in Akureyri, Island, in 2014 (Oddsdóttir et al. 2015).

One theme of importance for gender equality in the Arctic region that is the focus in this article is the wellbeing of the aging population and how the needs of the elderly are provided for in private and public spheres -by the family, local communities, the state and the market. The Nordic welfare state model and its adherence to gender equality has been studied extensively (Gunnarsson 2013; Pylkkänen 2009; Lister 2009, 242-78; Wennberg 2008) but has not been directed to a specific region. The principle of gender equality is mostly dealt with as a nation-state, European and European Union issue. When addressing the international legal objectives of gender equality, research has often taken as its starting point international treaties, such as the CEDAW (Hellum and Aasen 2013).

In this article, the complexity of the public and private division of welfare provision and care of the elderly in the Swedish Arctic context is addressed and discussed in the light of national, regional and international policy and law. The county of Norrbotten, the northernmost county in Sweden that is part of the Barents Euro-Arctic region - Europe's largest region for interregional cooperation - is taken as a frame of reference for critical reflection on how Swedish welfare policy and the law for older people in need works in this specific context. Being at the center of measures for the redistribution of wealth, welfare state policy and law involve a number of sectors that participate in the construction of generational and gender relations, such as caring within families, healthcare and care of the elderly. Social and health needs, as these are normatively constructed in welfare state policy and law, however, mainly seem to emanate from living conditions and problems identified in urban contexts.

In Sweden, elder law appeared as a legal discipline in its own right later than in the Anglo-Saxon contexts. The Norma Elder Law Research Environment at Lund University in the south of Sweden embraces different approaches with both European Union and Swedish points of reference (Numhauser Henning 2013; Albertson Fineman, Mattsson and Andersson

\footnotetext{
${ }^{3}$ Arctic Council. 2009. Arctic Council's Sustainable Development Working Group.
} 
2017). Ageing in specific contexts, such as the northern and Arctic regions, has not previously been an issue in legal studies but, more recently, in interdisciplinary analyses, e.g. by scholars in sociology and social, cultural and critical gerontology. Here, ageing, wellbeing and climate change in the unique Arctic context, shaped by the region's changing climate as well as its nature, local traditions, social relationships and different forms of support for coping with everyday life, which may either support or threaten the wellbeing for ageing people, has been analyzed in a gender-based perspective (Naskali, Seppänen and Begum 2016). Feminist approaches are also active here, aimed at giving voice to under-represented, marginalized groups of women, whose voices are in danger of being drowned by those who represent the values of the majority (Tapio 2010, 2016).

Forms of discourse analysis, cultural studies, feminism and post-modern schools of thought have gained ground within socio-legal research (Banakar and Travis 2005). The socio-legal approach in this article represents "an interface with a context within which law exists" (Wheeler and Thomas 2002, 271). This approach is used to recognize the diversity in ageing and how the application of this diversity to rural locations and ethnic and national minorities forms part of the structural processes of exclusion. The position of human rights and the legal status of national minorities also come into the question. The operation of economic, political and social processes on an increasingly global scale implies that welfare services and care provision for ageing people, in addition to the context of national welfare systems, also has to be seen in the context of regional and international policy and law. The point in the socio-legal approach taken here is that wellbeing and gender equality also need to be seen against the various local and specific contexts in which people age and probably become in need of welfare services and care provided by public as well as private providers. Multi-levelled governance on ageing, such as the Madrid International Plan on Ageing 2002, ${ }^{4}$ and CEDAW documents, such as the CEDAW general recommendation No. 27 on older women and protection of their human rights ${ }^{5}$, and the CEDAW general recommendation No. 34 on the rights of rural women ${ }^{6}$, are taken as starting points for highlighting the need to develop alternative political and legal interventions that are better adjusted to meet the everyday needs in this specific setting. The point of departure for reflecting critically on Swedish law and policy for providing welfare services and care for the elderly in need in this region, is that there

\footnotetext{
${ }^{4}$ United Nations 2002. Political Declaration and Madrid International Plan of Action on Ageing. Second World Assembly on Ageing, Madrid, Spain, 8-12 April.

${ }^{5}$ CEDAW/C2010/47/GC.1. General recommendation No. 27 on older women and protection of their human rights (2010).

${ }^{6} \mathrm{CEDAW} / \mathrm{C} / \mathrm{GC} / 34$. General recommendation No. 34 on the rights of rural women (2016).
} 
are specific gender-based living conditions and diversity in social and cultural ageing (Jamieson 2002, 7-20) that need to be considered as a gender equality issue.

\section{The context - a multi-cultural, sparsely populated and gender-segregated place}

The northernmost parts of Sweden, Norway, Finland and Northwest Russia are part of the Barents Euro-Arctic region. The nature is unique and the environment vulnerable, with wide tundra areas in the north and extensive boreal zones in the south (Barents info.org no date). Historically, this county, located in the Barents Euro-Arctic region, could be characterized by mobility, in ancient times and still often in the east-west direction, and by various cultures and languages: Sami, Swedish and Finnish. Before the border between Finland and Sweden was drawn through the Torne River in 1809 , the area was distinctly multicultural. The predominant languages in the Torne River valley - Tornedalen - were the Sami and the Finnish-Ugrian minority language meänkieli. The forn-Nordic Swedish language that was spoken during the 14th century, has been retained by people living in the valley of one of the other main rivers in the county - the Kalix River - that for many centuries was the only means of communication with the rest of Sweden. This inner part of the county of Norrbotten represents the northernmost Swedish culture in the nation. The very special Swedish dialect spoken here has survived through the centuries and constitutes the oldest relic of the language that was used by the Vikings (Hederyd and Hansson 1982). More recently, in 1999, the Meänkieli-speaking people, together with the Sami and Roma people, were actually recognized as national minorities when Sweden signed up to the European Council Framework Convention for the Protection of National Minorities. ${ }^{7}$

Earlier research has pointed to the creation and preservation of the idea of northern Sweden as consisting of exotic, scenic, but very different and faraway places and to this part of Sweden being viewed as different, idealized but marginalized (Overud 2013, 195). Sparsely populated, geographically widespread and rural Nordic areas nevertheless have their social and gendered structure. These areas share a common problem of maintaining labour market participation for both men and women. Labour markets in such regions are often characterized by a skewed gender balance, strong gender segregation and the offer of few employment opportunities, particularly for women (Overud 2013, 193-213).

\footnotetext{
${ }^{7}$ Council of Europe. 1995. ETS No.157. Framework Convention for the protection of national minorities.
} 
During the last century, the extraction of natural resources in the form of forestry and mining has played a crucial role in job-creation and economic wealth in the region, at the same time as the exploitation has led to the deterioration of the environment and living conditions, especially for reindeer herding and indigenous people. Women in this, like in other parts of Sweden, have largely occupied the position of secondary earners, performing un-paid care work in the family, although most women have also had part-time or full time paid work in various private and public sectors of society.

Major structural and demographic changes have taken place in Norrbotten, especially during the last 50 years. Mobility and adaptability were key words in Swedish labour market policy in the 1960s, directing labour geographically from places with high unemployment rates to those with a high demand for labour (Overud 2013). This has led to a shrinking and ageing population as the younger people left the region to earn a living. It is the young women in particular who have left the region (Statistics Sweden 2014). The population of Sweden is projected to grow by 12 percent between 2012 and 2030. The Arctic regions are projected to grow much more slowly, with Norrbotten at 1.7 percent (Statistics Sweden 2014). As claimed by Andrew (2014), projected growth in Norrbotten is dependent entirely on net in-migration, with deaths expected to exceed births throughout the projection period, and population starting to decline from 2028 as net in-migration is insufficient to counter natural population decline. The aging, shrinking and gender-skewed balance implies sparse tax revenues and that the geographically extended and financially "poor" municipalities lack the financial and human/personnel resources needed to meet the statutory local responsibility to provide welfare services and care for elderly people in need. In addition to the shrinking, gender-skewed and ageing population, the increased in-migration of foreign women who come to live with local men (Burman 2012) adds new and future gender-relational and multicultural challenges to be handled in the local communities (SOU series 2012:45).

\section{New governance to meet "a tsunami of old people"}

When the demographic shift towards an older population is discussed as a major challenge all over the world the talk is of a silver tsunami of ageing people. The aging of the post-war generation, low fertility rates and rising life expectancy are understood to constitute crucial aspects in restructuring the welfare state and resource allocation between age groups. The fiscal consequences of an aging society attract great political attention since the welfare state in general is understood to play an important role in the 
solidarity between generations (Powell and Hendricks 2009). In the restructuring of the welfare state, the perception of old age as a burden on society's economic health is expressed. Moreover, social and demographic transformation is perceived to constitute a threat to collective social welfare and solidarity between generations and social citizenship. This latter concept, which comprehends the rights and duties, including the distributive principles and participatory conditions which enable membership in a society (Wennberg 2004, 36), is a concept commonly and theoretically used as an instrument for analysing gender, equality and welfare regimes (Wennberg 2008; Gunnarsson 2007; Lister 2003; Hirschman and Liebert 2001). Today, the normative Swedish model of social citizenship, i.e. the strong state involvement in the care of children and the elderly, has been put to the test. As argued by Powell and Hendricks (2009) the aging population is understood as participating in restructuring the welfare state and resource allocation between age groups. Since the welfare state is at the centre of the redistribution of resources, the aging society, in this view, involves struggle and competition over scarce resources with fiscal consequences.

Current changes in welfare legislation take place in the context of internationally agreed legal objectives and policies, and economic globalisation, all of which impact on legal regulation and on the discursive ways of representing social reality (Wennberg 2008). Understood as "new governance" it extends deep into nation states, not necessarily through social policies as is conventionally understood, but rather in terms of shaping discourses and processes through subtle patterns of influence on, and the insinuation of, particular values, ways of thinking and agency (Wennberg 2008, 134). Somek (2011, 56-7) challenges the European integration project in his critical writing from a humanist perspective. He claims that new governance is about creating competitive laboratories for the purpose of permanent policy adjustments - a move away from law to management. In his view, new governance strategies differ from a legal regime for the protection of rights. New governance, he claims, defies legality but invites positive initiative with regard to the development of new standards and strategies. In this view, policy and law for ensuring wellbeing and gender equality for aging people in various parts of the northern and Arctic region need not only to be analysed in the context of national and/or local welfare regimes, but also in the context of the commonly agreed objectives and policies on regional and international levels.

The challenge of ageing, identified as a problem all over the world, is approached by new governance as a tool for policy adjustments. In 2002, the United Nations' Second World Assembly on Ageing adopted, as a main 
development objective, the Madrid International Plan on Ageing, ${ }^{8}$ which includes the recognition that persons, as they age, should enjoy active participation in the economic, social, cultural and political life of their societies. Active ageing as an objective has also become part of the EU agenda, firmly established by the European Parliament's decision regarding the European Year for Active Ageing and Solidarity between Generations 2012. ${ }^{9}$

The concept of active ageing is expressed by the European Commission as "helping people stay in charge of their own lives for as long as possible as they age and, where possible, to contribute to the economy and society". ${ }^{10}$ According to the EU Treaty (TEU), and its Article 3, solidarity between generations is one of the Union's goals. Moreover, Article 25 in the European Union Charter of Fundamental Rights, ${ }^{11}$ declares that "the Union recognizes and respects the rights of the elderly to lead a life of dignity and independence and to participate in social and cultural life". The EU includes the commonly agreed objectives of combating social exclusion and discrimination, of promoting social justice and social protection, and of gender equality Art. 3 (3) Treaty on European Union (TEU). The strategy of mainstreaming gender that is laid down in Article 8 Treaty on the Functioning of the European Union (TEUF) is an important mechanism for promoting these objectives. Overall, the measures taken that mostly have the character of soft law, have an impact on national welfare models, ranging from the substantial welfare regimes modelled on the nation state, to anti-discrimination and individual rights claims (Wennberg 2008, 131-217; Somek 2011).

The conceptualization of ageing as active has accordingly become a topic given increasing attention in scientific and policy discussions, although there seems to be no consensus about its actual meaning, and the topic is subjected to critical investigation (Boudiny 2013, 1077-98). The emergence of a dominant discourse and its effects on a policy-based understanding of ageing in international and European policy, is critically analysed as representing a new orthodoxy of ageing subjectivity, restricting the social contribution of older adults to work and work-like activities (Moulaert and Biggs 2012, 23-43).

\footnotetext{
${ }^{8}$ United Nations (2002).

${ }^{9}$ Decision No 940/2011/EU of the European Parliament and of the Council of 14 September 2011 on the European Year for Active Ageing and Solidarity between Generations (2012).

${ }^{10}$ European Commission. Employment and Social Affairs. Active Ageing.

${ }^{11}$ Charter of Fundamental Rights of the European Union, Official Journal of the European Union, OJ C 83, 30.3.2010, 389-403.
} 


\section{Elder services and care at the intersection of public and private spheres}

The Swedish welfare model is residence-based and gender-neutrally constructed. The system that was originally based in the Social Democrat values of "positive freedom" and equality is founded on general principles of solidarity and public responsibility, rather than individual rights and individual interests. In Sweden extensive welfare policies have projected the impression of overall equality and social citizenship. Gender equality and the notion of social citizenship in the Swedish and the other Nordic welfare models have, as argued by Nousiainen (2001, 25-77) been strongly linked to the consideration of care as a collective public responsibility rather than an individual and private one, expressed in terms of a caring state liberated from conservative and neoliberal hegemony. Nordic welfare states have an extremely high level of social service provision compared to most other countries. Accordingly, the Nordic welfare state is not only a 'caring state' and 'social insurance state' but also to a great extent a 'service state' (Sipilä, Anttonen and Kröger 2009, 181-99). These characteristics have led to the vision of a woman-friendly welfare state, criticized, however, for being based on a market-oriented concept of economic gender equality, which has proved to be a limiting factor as the care economy rationales have not been fully recognized for reforms that involve public budgeting (Gunnarsson 2013, 38-56).

Public elderly care is one of the largest and most rapidly changing welfare sectors in Sweden. It is also one of the most gendered, for several reasons. The expansion of the public care sector was crucial in giving women access to the labour market and care work is still coded as female work and dominated by female workers. Jobs have low status, are badly paid, often performed on a part-time basis and in several aspects are considered precarious work. The home-based ideology has remained dominant within public elderly care. Most care work is performed at the intersection of the public and private spheres: organized and administrated by the public but situated in the context of the private homes of the elderly (Andersson 2013, 170-89).

The new politics of the Nordic welfare states is, in many ways, reflected in welfare services and care provision. Increased means-testing and the introduction of standardized and evidence-based methods for the assessment of needs under the Swedish Social Services Act (SFS 2001:453), characterize the practice of policy and law in the municipalities, especially it is shown, in relation to social services for the elderly (Proposition 2009/10:116). The political ambition to unleash the many new entrepreneurs and providers within healthcare and social welfare services is representative of one of the shifts taking place in the transforming 
Swedish welfare state, which is the promotion of social investment calling for an increase in the employment rate and increased investment in human capital (Sipilä, Anttonen and Kröger 2009, 187). In the 2009 Act on System of Choice (SFS 2008:962) in the public sector came into force within healthcare and social welfare services. As a result, in order to meet the political demands for free choice for elderly citizens, many of the Swedish municipalities have increased the scope of private alternatives in the provision of services and care. This new approach in Swedish social policy has also found expression in the introduction of choice in primary care, deregulation of the pharmacy market, freedom of choice in childcare and tax deductions for household services. Privatization in elderly care means out-sourcing, with different care companies competing for contracts, while care provision remains a public matter, financed through tax revenues (Andersson 2013, 170-89).

Informalization and refamilialization of care also come into the picture, especially in the field of services for the elderly. The responsibility for carrying out services which have primarily been a public responsibility is now shifted back to families and from the state to local communities. Within Swedish research on these transformations in the welfare state lies proof of the negative consequences for close persons/relatives who provide care for the elderly within the family: in daily life, in working life and economic position (Meagher and Szebehely 2013). The process of the informalisation of care, however, is not, as a Finnish view claims, concerned as much with the return of responsibility to families and local communities as with the minimization of the costs associated with the ever-increasing burden of care (Sipilä, Anttonen and Kröger 2009, 171).

Another important aspect to reflect on concerning the wellbeing of ageing people in a northern and Arctic context is housing. In the Swedish welfare state, good housing has been a key value since the 1930s and 1940s which has also found expression as a public responsibility in the Swedish Instrument of Government (SFS 1974:152). Recently, the Swedish National Audit Office has pointed out that housing for the elderly in depopulated areas is a problem that government needs to take measures to solve (Riksrevisionen). The Swedish Housing Act (SFS 2000:1383), states that every municipality has the responsibility to plan for housing in order to create good living conditions for everyone in the municipality. The government, however, has not identified housing as being within the scope of Services of General Economic Interests according to EU law (COM (2011) 900 final), which would allow public measures to be taken in an area that is primarily considered to be taken care of by the market and private market investors. According to the National Audit Office, the government has not done enough to tackle the housing problem for older people, shown to be 
particularly striking for those living in depopulated parts of northern Sweden. Old people end up in a situation where moving is not an option as there is no alternatives housing available. Elderly people, especially women who live longer than men (Statistics Sweden 2017) therefore end up at risk of having difficulties accessing services important for their well-being since there is no transport to the places where commercial and social services of various kinds could be provided.

\section{A reasonable standard of living?}

In Sweden public elderly care is regulated in the Social Services Act (SFS 2001:453). This Act has a framework construction, which means that it is the responsibility of the local Social Service Board to realize and ensure provision of the stated social objectives i.e. living safely and independently and having an active and meaningful existence together with others. ${ }^{12}$ Moreover, the social services are responsible for promoting housing of good quality for the elderly and assisting with domestic help and service if needed. It is the responsibility of the municipality to establish special housing for old people who are in need of special support. The older person should, as far as possible, be able to choose when and how housing and other easily accessible services should be provided..$^{13}$

Regardless the above-mentioned objectives, the assessment of whether a person is or is not entitled to services in the home or special housing is made according to Chapter 4 section 1 in the Social Services Act. This section, which could be characterized as a claim right, states that the individual has a right to the various forms of support and assistance needed for being ensured a reasonable standard of living, if the need cannot be met by him or herself or by other means.

New national values for older people, echoing the internationally agreed wellbeing objective for the elderly, were inserted into the Social Services Act in 2010, formulated as living in dignity and having a feeling of wellbeing. These new values were meant to clarify the fundamental, normative and ethical values for elder care and were construed as a means of steering of the management of care services. In the preparatory work for the new legislation, the government indicated the supposition that there would still be differences in how the municipalities chose to organize, prioritize and carry out welfare services. However, the government deemed that elderly people, by means of the new statutory values, should be given equal possibilities throughout the whole country to live in dignity (Proposition 2009/10:116). These values, however, do not form the legal base for

\footnotetext{
${ }^{12}$ Social Services Act (SFS) 2001:453, Chapter 5 section 4.

${ }^{13}$ Social Services Act (SFS) 2001:453, Chapter 5 section 5.
} 
assessing whether a person is eligible for assistance and welfare services in order for them to be assured of a reasonable standard of living. Municipal autonomy, different economic/financial conditions and the political priorities made in each municipality, entail a risk of inequality in results and discriminatory practices. There are court cases ${ }^{14}$ that show how the concept of a reasonable standard of living is interpreted differently in the municipalities, depending on how the law is interpreted and the political as well as the professional priorities made in each municipality.

In 2010, a new Act (2009:724) concerning national minorities and minority languages came into force, which makes the municipalities in certain administrative areas (förvaltningsområden) where minority languages are used, responsible for providing services and care by personnel who have language skills in Finnish, Sami, and Meänkieli. In preparatory works for the Act it was, however, stipulated that the new regulation could not constitute a claim right for those using a minority language. Rather than imposing an immediate responsibility to employ staff with skills in minority languages, the new regulation was merely considered to constitute a qualification/merit at recruitment (Proposition 2008/09:158). The parliamentary Ombudsman (JO) that is appointed by the Swedish Parliament to ensure that public authorities and their staff comply with the laws and other statutes governing their actions, has tested the compliance with this regulation and confirmed the limited reach of this Act (JO 2010:11:JO1).

\section{Conclusion}

Transformations in the welfare state as well as social and demographic changes affect the wellbeing of aging people and their living conditions in the north. As well, the paradigmatic shift in social policy and law related to Europeanization and globalization transcend the formation of legal knowledge. This shift implies transformation of the welfare state into the welfare society, with an anti-regulatory ideology as well as shift in the public/private division, moving from state power to individual autonomy. The introduction of national values for elder care in the Swedish Social Services Act is representative of the new balance between legal principles and the protection of substantive equality. These new values, formulated to promote living in dignity and wellbeing, were meant to clarify the fundamental normative and ethical values for elder care and were construed as a means of steering of the management of care services. The Government considered that older people should, by means of statutory

\footnotetext{
${ }^{14}$ For example, see Supreme Administrative Court (2007), Yearbook ref. 86; Administrative Court of Appeal, Gothenburg, case 4683-2014; Administrative Court of Appeal, Stockholm, case 1818-14.
} 
values, be given equal possibilities throughout the whole country to live in dignity. However, there will still be differences in how the municipalities choose to organize, prioritize and perform welfare services, depending on the financial situation and political will in each municipality. These new values, however, still do not form a legal basis to assess whether a person is entitled to the welfare services or care needed for a reasonable standard of living. Moreover, standardization of the assessments of needs, based on the notion of evidence, may not take into account everyday life and contextual conditions in rural northern areas.

None of the abovementioned transformations sufficiently seem to take into consideration the living conditions in rural contexts, characterized by an age- and gender-skewed balance in the population, often without family members to rely on as they have left to find work or to study. Poor municipalities lack the financial and human/personnel resources needed to take local responsibility to provide welfare services and care for elderly people in need. At the same time, the market does not see such depopulated areas as profitable enough to invest in. Free choice is not therefore in reality an option for elderly people living in these kinds of rural northern and Arctic areas.

Could human rights and discrimination law, in a welfare state in change, then be a tool for strengthening the wellbeing and gender equality for elderly people in northern and Arctic contexts? In feminist legal studies, it is argued that gender equality, in the formal sense, means assimilation and harmonization based in certain standards that everyone has to adapt to (Davies 2008; Pylkkänen 2009). There is also criticism claiming that antidiscrimination law, even though distributive in its orientation, does not recognize any distributive patterns and therefore, not by accident, is concomitant to neoliberalism (Somek 2011). Among feminist legal scholars, intersectionality is also discussed theoretically in relation to antidiscrimination law, which is often criticized for its inability to influence circumstances in reality, i.e. equality and social justice in the material sense (Kantola and Nousiainen 2009; Pylkkänen and Wennberg 2012, 12-28). In my view, wellbeing and gender equality for aging people in the Arctic, cannot only be seen in the formal sense as a question of equal rights and protection against discrimination, but needs also to link to social rights and responsibilities in the welfare state (Wennberg 2012; 2013, 57-79). In-depth analysis of the intersection of gender, age, ethnicity and social class in the public and private division of welfare services and care in rural, depopulated and multicultural contexts should aid a better understanding of the living conditions of the elderly in northern and Arctic Sweden and contribute to the development of alternative policy interventions on relational, institutional and structural levels. 
There are reasons for further socio-legal analysis of elder care and services as a gender equality issue in the context of northern and Arctic regions. One reason is that women in general live longer than men and therefore, probably more often than men, come to need care and welfare services. How women's living conditions and needs for care as they age in northern and Arctic regions are affected by the increased emphasis on active ageing, and by the meaning this concept is given in various social and cultural contexts also need further scrutiny. The concerns over the threats to social solidarity between generations have been understood globally through the generational contract. Some claim that the demographic threat is being used as an ideological platform for a more neoliberal attack on the welfare state in favor of both private insurance and greater personal responsibility for our own and our family's future. If welfare-state support and services erode, there is a greater potential burden placed on family members to provide familial care, but with greater geographical mobility, families are often not there to provide the care provided by children for parents in the traditional extended family that frequently no longer exists in rural and depopulated areas. Furthermore, the burden of family care tends to fall unequally on women, thereby reinforcing gender inequalities.

Being at the centre of the redistribution of resources, which involves a number of sectors, such as caring within families and care for the elderly, the welfare state helps shape and induce gender (in) equalities. Legal and policy discourses play an important role in creating and reinforcing specific sets of social values and expectations attached to gender-a set of norms and relations embedded within the social structure-involved in the ideological process in society. Examining which discourses are dominant, which discourses are silenced, how this happens and what legal strategies are used could reveal the indefinableness in hegemonic interventions and the alternative interventions at the intersection of public and private spheres that could be developed. The gendered dimensions of social power within the structure of welfare state regulations and new governance that are directed towards managing or regulating social practices, are aspects of the balance and boundaries between politics and law. Are old women and men, from various cultures, ethnicities and minority groups, in different parts of the Arctic region, guaranteed a life in dignity and wellbeing? The question is motivated in view of the ideological (and neo-liberal) idea of active ageing; the space there is for local priorities and; the unequal conditions, financially and humanly, that exist in the Arctic region. These above-mentioned power imbalances in policy and law, and their impacts on gender equality, underline the importance of a framework for comparative analyses of services and care in the Arctic. In light of internationally agreed objectives, national welfare systems need to be subjected to further socio-legal and 
interdisciplinary analyses in the context of the various local and specific conditions in which people age/grow old.

\section{References}

\section{Official documents}

Administrative Court of Appeal, Gothenburg, case 4683-2014.

Administrative Court of Appeal, Stockholm, case 1818-14.

Arctic Council. 2009. Arctic Council's Sustainable Development Working Group. https://oaarchive.arctic-council.org/handle/11374/37 (Accessed 2017-05-01).

Arctic Council's Sustainable Development Working Group [SDWG]. Arctic Human Health Expert Group (AHHEG). 2010. Proposal for a Comparative Review of Circumpolar Health Systems [CircHSR]. https://oaarchive.arctic-council.org/handle/11374/987 (Accessed 2017-0515).

CEDAW/C2010/47/GC.1. General recommendation No. 27 on older women and protection of their human rights (2010).

CEDAW/C/GC/34. General recommendation No. 34 on the rights of rural women (2016).

COM (2011) 900 final Brussels, 20.12.2011. A Quality Framework for Services of General Interest in Europe. Communication from the Commission to the European Parliament, the Council, the European Economic and Social Committee and the Committee of the Regions.

Council of Europe. 1995. ETS No.157. Framework Convention for the protection of national minorities. http://conventions.coe.int/Treaty/en/Treaties/html/157.htm (Accessed 2017-05-15).

Decision No 940/2011/EU of the European Parliament and of the Council of 14 September 2011 on the European Year for Active Ageing and Solidarity between Generations (2012) http://eur-lex.europa.eu/legalcontent/EN/TXT/?uri=CELEX:32011D0940 (Accessed 2017-05-16).

European Commission. Employment and Social Affairs. Active Ageing. http://ec.europa.eu/social/main.jsp?catId=1062 (Accessed 2017-05-19).

JO 2010:11:JO1, [Case from the Parliamentary Ombudsman] JO 2010:11:JO1, Case no. 2009-7179, 2010-06-08, Kiruna kommun (Swed.).

Proposition 2008/09:158, Från erkännande till egenmakt. Regeringens strategi för de nationella minoriteterna [Government bill 2008/09, From Recognition to Empowerment. Government Strategy for National Minorities] (Swed.). 
Proposition 2009/10:116, Värdigt liv i äldreomsorgen [Government bill 2009/10, Life in Dignity in Elder Care] (Swed.).

Riksrevisionen, Bostäder för äldre i avfolkningsorter. RIR 2014:2 (2014) [National Audit Office, Housing for elderly in rural Sweden] (Swed.). http://www.riksrevisionen.se/sv/rapporter/Rapporter/EFF/2014/Bostad er-for-aldre-i-avfolkningsorter/ (Accessed 2017-04-26).

SFS 1974:152, Regeringsformen [Swedish Instrument of Government] (Swed.).

SFS 2000:1383, Lag om kommunernas bostadsförsörjningsansvar [The Swedish Housing Act] (Swed.).

SFS 2001:453, Socialtjänstlag [Swedish Social Services Act] (Swed.).

SFS 2008:962, Lag om valfrihetssystem [Act on System of Choice] (Swed.).

SFS 2009:724, Lag om nationella minoriteter och minoritetsspråk [Act on minorities and minority languages] (Swed.).

SOU series 2012:45, Kvinnor och barn i rättens gränsland [Swedish Official

Report Series (SOU) 2012:45, Women and Children at the Borders of Law] (Swed.).

Supreme Administrative Court (2007), Yearbook ref. 86 (Swed.).

United Nations. 2002. Political Declaration and Madrid International Plan of Action on Ageing. Second World Assembly on Ageing, Madrid, Spain, 812 April. http://www.un.org/en/events/pastevents/pdfs/Madrid_plan.pdf (Accessed 15 May 2017).

\section{Literature}

Albertson Fineman, Martha, Mattsson, Titti and Andersson, Ulrika (eds.). 2017. Privatization, Vulnerability, and Social Responsibility. A Comparative Perspective. London: Routledge.

Andersson, Katarina. 2013. Freedom of Choice in Swedish Public Care of the Elderly. In Åsa Gunnarsson (ed.). Tracing the Women-Friendly Welfare State. Gendered Politics of Everyday Life in Sweden. Stockholm: Makadam, 170-89

Banakar, Reza and Travers, Max. 2005. Theory and Method in Socio-Legal Research. Oxford: Hart Publishing.

Barents info.org. (no date). Your window to the Barents Region. http://www.barentsinfo.org/Barents-region (Accessed 2017-04-27).

Boudiny, Kim. 2013. Active Ageing: from empty rhetoric to effective policy tool. Ageing and Society 33 (06): 1077-98.

Burman, Monica. 2012. Immigrant Women Facing Male Partner Violence Gender, Race and Power in Swedish Alien and Criminal Law. feminists@law2 (1) (E-journal).

Davies, Margaret. 2008. Asking the Law Question. $3^{\text {rd }}$ ed. Sydney: Lawbook. 
Gunnarsson, Åsa (ed.). 2013. Tracing the Women-Friendly Welfare State. Gendered Politics of Everyday Life in Sweden. Stockholm: Makadam.

Gunnarsson, Åsa. 2007. Gender Equality and the Diversity of Rights and Obligations in Swedish Social Citizenship. In Åsa Gunnarsson, Eva-Maria Svensson and Margaret Davies (eds.). Exploiting the Limits of Law. Swedish Feminism and the Challenge to Pessimism. Aldershot: Ashgate, 191-211.

Gunnarsson, Åsa. 2013. Tax Law Directions for Erasing the Public/Private Divide in Everyday Life Economy. In Åsa Gunnarsson (ed.). Tracing the Women-Friendly Welfare State. Gendered Politics of Everyday Life in Sweden. Stockholm: Makadam, 38-56.

Hirschman, Nancy J. and Liebert, Ulrike (eds.). 2001. Women and Welfare: theory and practice in the United States and in Europe. New Brunswick, New Jersey and London: Rutgers University Press.

Hederyd, Olof and Hansson, Ulf. 1982. Från stenhacka till järntacka. Överkalix: sockenhistoria. Part 1. Överkalix: Överkalix Municipality.

Hellum, Anne and Aasen, Henriette (eds.). 2013. Women's Human Rights. CEDAW in International, Regional and National Law. Cambridge: Cambridge University Press.

Jamieson, Anne. 2002. Theory and Practice in Social Gerontology. In Anne Jamieson and Victor C. Minichello (eds.). Researching Ageing and Later life. Buckingham Philadelphia: Open University Press, 7-20.

Kantola, Johanna and Nousiainen, Kevät. 2009. Institutionalizing Intersectionality in Europe: Legal and Political Analyses. International Feminist Journal of Politics 11 (4): 459-77.

Lahey, Kathy, Svensson, Eva-Maria and Gunnarsson, Åsa. 2014. Gender Challenges \& Human Capital in the Arctic. Arctic Yearbook: 183-201.

Lister, Ruth. 2009. A Nordic Nirvana? Gender, Citizenship and Social Justice in the Nordic Welfare State. Social Politics: International Studies in Gender, State \& Society Online 16 (2): 242-78.

Lister, Ruth. 2003. Citizenship: Feminist Perspectives. Second edition. Basingstoke: Macmillan.

Meagher, Gabrielle and Szebehely, Marta. 2013. Marketisation in Nordic eldercare: a research report on legislation, oversight, extent and consequences. Stockholm: Stockholms universitet. Institutionen för socialt arbete.

Moulaert, Thibauld and Biggs, Simon. 2012. International and European policy on work and retirement: Reinventing critical perspectives on active ageing and mature subjectivity. Human Relations 66 (1): 23-43.

Naskali, Päivi, Seppänen, Marjaana and Begum, Shahnaj (eds.). 2016. Ageing, Wellbeing and Climate Change in the Arctic: An Interdisciplinary Analysis. London and New York: Routledge. 
Nousiainen, Kevät. 2001. Transformative Nordic Welfarism. Liberal and Communitarian Trends in Family and Market Law. In Kevät Nousiainen, Åsa Gunnarsson, Karin Lundström and Johanna Niemi-Kiesiläinen (eds.). Responsible Selves. Women in the Nordic Legal Culture. Aldershot: Ashgate, 25-77.

Numhauser Henning, Ann (ed.). 2013. Introduction to the Norma Elder Law Research Environment. Different Approaches to Elder Law. Lund: Lund University, Faculty of Law.

Oddsdóttir, Embla Eir, Sigurðsson, Atli Már, Swandal, Sólrún and Árnadóttir, Anna Kolbrún. 2015. Conference Report. Gender Equality in the Arctic. Current Realities, Future Challenges. Ministry for Foreign Affairs, Iceland in cooperation with Icelandic Arctic Cooperation Network and the Centre for Gender Equality.

Overud, Johanna. 2013. Integration to Segregation. In Åsa Gunnarsson (ed.). Tracing the Women-Friendly Welfare State. Gendered Politics of Everyday Life in Sweden. Stockholm: Makadam, 193-213.

Parkinson, Alan J. 2013. The Arctic Human Health Initiative: A legacy of the International Polar Year 2007-2009. Sustainable Development Working Group (SDWG). http://hdl.handle.net/11374/1654 (Accessed 2017-05-05)

Powell, Jason L. and Hendricks, Jon (eds.). 2009. The Welfare State in PostIndustrial Society. A Global Perspective. Heidelberg: Springer.

Pylkkänen, Anu and Wennberg, Lena. 2012. Intersektionalitet i rätten - en metod för att synliggöra det osynliggjorda. Retfærd 35 (3): 12-28.

Pylkkänen, Anu. 2009. Trapped in Equality. Women as Legal Persons in the Modernisation of Finnish Law. Helsinki: Finnish Literature Society.

Sipilä, Jorma, Anttonen, Anneli and Kröger, Teppo. 2009. A Nordic Welfare State in Post-Industrial Society. In Jason L. Powell and Jon Hendricks (eds.). The Welfare State in Post-Industrial Society. A Global Perspective. Heidelberg: Springer, 181-199.

Somek, Alexander. 2011. Engineering Equality. An Essay on European AntiDiscrimination Law. Oxford: Oxford University Press.

Statistics Sweden. 2014. Inrikes flyttning 2013. Var åttonde person flyttade under 2013. http://www.scb.se/sv_/Hitta-statistik/Artiklar/Var-attondeperson-flyttade-under-2013/ (Accessed 2017-05-13).

Statistics Sweden. 2017. Hög medellivslängd i Sverige. http://www.scb.se/sv_/Hitta-statistik/Artiklar/Hog-medellivslangd-iSverige/ (Accessed 2017-05-15).

Tapio, Tarja. 2010. We all have the same stories: storytelling case study about ageing in Tornedalen in the perspective of everyday life and future. Jyväskylä Studies in Education, Psychology and Social Research 395. Jyväskylä: Jyväskylänyliopisto. 
Tapio, Tarja. 2016. 'Our forest': ageing, agency and 'connection with nature' in rural Tornedalen, northern Sweden. In Päivi Naskali, Marjaana Seppänen and Shahnaj Begum (eds.). Ageing, Wellbeing and Climate Change in the Arctic. An interdisciplinary analysis. London and New York: Routledge, 196-212

Wennberg, Lena. 2004. Social Assistance for Solo Mothers in Sweden, Finland, Norway and Denmark. A comparative legal study. Umeå Studies in Law No 8/2004.

Wennberg, Lena. 2008. Social Security for Solo Mothers in Swedish and EU Law. On the Constructions of Normality and the Boundaries of Social Citizenship. Uppsala: Iustus.

Wennberg, Lena. 2012. Constructions of Normality and the Boundaries of Social Citizenship - Solo Mothers in the Swedish Welfare Model. feminists@law2 (1) (E-journal).

Wennberg, Lena. 2013. Neoliberal Trends in the Women-Friendly Welfare State. In Åsa Gunnarsson (ed.). Tracing the Women-Friendly Welfare State. Gendered Politics of Everyday Life in Sweden. Stockholm: Makadam, 57-79.

Wheeler, Sally and Thomas, Phil. 2002. Socio-Legal Studies. In David J. Hayton (ed.). Law's Future(s). Oxford: Hart Publishing, 267-280.

\section{Notes on contributor}

Lena Wennberg, LLD, Master of Social Work, is senior lecturer at Forum for Studies on Law and Society, Umeå University. 